第 3 群 : 放射性昇采を皮下注射し，1週間後同量の非 放射性水銀を皮下注射

実験は 2 回くり返され，第 1 回目の昇祕投与量は各注 射とも，水銀として $0.5 \mathrm{mg} / \mathrm{kg}$ ，第 2 回目の実験では $0.1 \mathrm{mg} / \mathrm{kg}$ とした。動物は第 1 回の注射後， 2 週間経過 後に心臓穿刺により採血, 肝, 腎, 脾, 盲腸, 脳を剔出 し，その一部について，井戸型シンチレーション計测器 で放射性水銀を測定，別に每日，尿，康を採取して，矢 の放射性水銀を測定した。

この結果は，大約，つぎのごときものですずにFri-

berg によってなされて同様の実験結果と一部分はよく 符合した。

1.脳に敃いては，一度蓄積した水銀は置きかえられ ない。

2. 脾，盲腸に和いては，明らかな置きかえがタらられ る。

3.旰，督においては明らかな置きかえを証明できな W。

4.置きかえを受けた水銀は，主として尿から排墈さ れ，屎へは排泄されない。

5. 屎への排泄量は第 1 回投与，第 2 回投与のそれ攵 れにおいて，汪ぼ同じであるが，尿への排浛量は第 2 回 目の水銀投与時は第 1 回投与洔よりも少ない。

\section{9. 砥素の解毒に関する砥素}

大橋和夫，酉村正雄，上田喜一（東菌大衛生）

砋素中毒の解毒には，特効薬ともいらべき BAL(British Anti-Levisite) が知られているが，BAL は毒性 が強く，また油溶性のため，筋注のみにかぎられ，長い 間，注射部の疼痛を訴觉ること，その他，副作用が多 く，産業現場での応用には適しない。最近，当教穻に抹 いて，水銀中請の解毒に関する一連の研究をおこない， Dihydro-thioctic-acid (DTA) が BAL に匹敵する 成績を示した。そこで今回も，DTAを中心として，そ の他, D-Penicillamine, L-..Cysteine, Thioctic acid（TA）等をとりあげ，锉策現場でも，手軽に投与 できる砒素解毒剂を見つけるべく，小動物を使って実験 を括こなった。

ハツカネズミにより，吪素急性毒性に対する解毒効果 を、シロネズミでは慢性砒素中素に対する各解毒绪の効 果を判定した。

成績: $10 \mathrm{mgAS} / \mathrm{kg} の \mathrm{NaAs} \mathrm{O}_{2}$ 溶液を，それぞれ皮 下に投与し，解毒剤を砒素に対して，等モル，2 倍和よ び 4 倍モル投与し，経日的生存率をみたところ，BAL，
DAT，TA が良忷な成績を示した。

一方，シロネズミの慢性実験に括いては，100ppm As 溶液を 36 日間飲用させ，解毒剂を（DTA，TA $100 \mathrm{mg} / \mathrm{kg}$, BAL $6 \mathrm{mg} / \mathrm{kg}$, D-Penicillamine $7 \mathrm{mg} / \mathrm{kg}$. L-Cysteine $8 \mathrm{mg} / \mathrm{kg}$ ) を連日筋注した結果，DTA が 一番良䚮な体重增加を示し，DAL，D-Penicillamine がこれにつぎ，L-Cysteine は非治瘏群におとった。な 括60日間，250ppm As 飲用せしぬた重症動物の治療効 果穾験に拈いては，BAL が圧倒的な好成績を示し，D TAはこれに虰よばなかった。

慢性実験に使用したシロネズミの肝，执よび婜の臓器: 中，砒素量を Sandell 法にしたがい，演者の考案した 改良燚置を使用して定量をしたところ，いずれの場合に おいても, 治療群は, 非治潦群よりも含有量は少なく, 程度の蹰度を示し，体重回復的線とほぼ一致する成績を 示した。阔じく，肺，婜の病理標本を作製し，検鏡した 結果，治療群と非治療群の間に顕著な差が認められず, いずれの場合でも，退行性変化を示した。すなるち、こ の程度の量の解毒剂によっては, 病理組織像の変化を完 全に防ぐことはできなかった。

\section{4例の贉業性アルキール水銀中毒について}

鈴木継美，西井俊治，鹿島俊彦，勝沼晴雄

(東大公衛)

エチル橉酸水銀をメタノールに溶解する作業に良事し ていた 4 名にみられた中醤について報告する。

作業はエチル燐酸水銀を科量し，メタノールに溶解す る作業であるが，中毒発生後に同じ作栄を，フェニール， 醋酸水銀を代用物として，再現したところ，気中水銀浀: 度は $1.0 \mathrm{mg} / \mathrm{m}^{3}$ をこ光，作嶫員に水銀被曝があったこ とを確認できた。

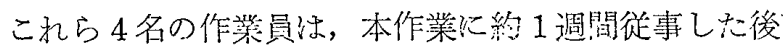
に, 各種の症状を示した。主たる症状は，口内炎，歯媲： 焱, 脱力感, 手のふる光, 不眠, 心のいらだちなどであっ た。曝露中止後，第 3 日目に行なった検查では，血中水 銀濃度が $100 \gamma / \mathrm{d} l$ 前後で，尿中水銀濃度は $10 \sim 20 \% / . \mathrm{d} l^{\prime}$ る示し，尿中水銀濃度に比较して，血中水銀濃度が高值 を示したことが注目された。全例に tremor，口内炎 が羿められ, 精神科的診察では hypochondric な状態 と診断された。毗底，視野に異常はなく，聴力は正常 で，運動失調は認わられなかった。尿蛋白，ウロビリー ゲン，替血，コプロポルフィリンは異常なかった。

頭痛，いらだち，不眠などの症状はクロルジアゼポキ サイド剂投与中は軽快与るが，投与中止によって再然し 